the older tickets? If they were ever produced it is unlikely that no specimen should remain. Perhaps, after all, they were made not of the breadth of an angel but considerably smaller. If so I would suggest that they were of the type figured in W. Boyne's "Tokens Issued in the Seventeenth Century," London, first edition, 1858, Pl. 36, No. 6. That piece (specimens of which exist in the British Museum and elsewhere) has on the obverse the device of a thistle, crowned, between the letters $\mathrm{C}$ and $\mathrm{R}$, surrounded by the inscription, "Pray for the King" ; the reverse bears the inscription, "Lord give Thy Blessing," in three lines within a beaded circle. Or else they may have been a bronze piece with a rose crowned on the obverse and a shield bearing the cross of St. George on the reverse, which I believe the late H. Montagu ${ }^{1}$ was wrong in assigning to Elizabeth's reign. The obverse inscription is indeed, "Rosa sine spinâ," but the reverse inscription ("Pro lege, rege, et grege") and the general appearance of the piece, which is, $I$ think, met with as a cast of the period as well as struck from dies, accord much better with the reign of Charles $I$. than with that of Elizabeth. It is quite likely that some document is missing and that after the order referred to by Miss Farquhar was made it was found for some reason inconvenient to issue tickets as broad as an angel. If, then, one cannot accept the size of the pieces as a criterion a third question remains to be solvedWhich type was the earliest one? That cannot apparently be answered at present.

There are still some surprises for those interested in touch-pieces. For instance, in the Wellcome Historical Medical Museum there is a silver touchpiece of the "Old Pretender," James III., exactly similar to the well-known one described in Medallic Illustrations (London, 1885, vol. ii., p. 315, No. 139), but instead of the obverse legend commencing with "IAC. 3" it commences with "IAC . 8." The specimen in question in the Wellcome Museum, though very much worn by rubbing, seems to be genuine, and there is no appearance of the legend having been tampered with. The "Old Pretender" was called James VIII. of Scotland as well as James III. of England, and some confusion of the die-engraver connected with this fact may account for the existence of the piece. No other specimens of this variety, as far as I know, exist in public or private collections. In the Wellcome Museum there is likewise an impression in bronze or copper struck from dies similar to those used at Rome for the touch-pieces of the last "Pretender," Henry IX., but the border is wanting and the breadth is therefore less. The piece is not pierced with a hole for suspension, and is probably a nearly modern impression, either from original dies very much "touched up" or from dies made in imitation of oxiginal ones. I believe that, at least up to 1870, visitors could obtain impressions, at fixed charges, from medallic dies preserved at the Papal Mint at Rome, and that when the dies of interesting and much sought for medals became worn out they were frequently replaced by copies. The original die for the obverse of the touch-piece of the "Old Pretender," described in Medallic Illustrations, vol. ii., p. 315, No. 139, is preserved in the British Museum collection, and it is possible that other original touch-piece dies are still in existence at Rome. I am, Sir, yours faithfully,

London, June EOth, 1914

F. PARKes Weber.

\section{SOCIETY OF TUBERCULOSIS OFFICERS.} To the Editor of THE LANCET.

SIR,-The purposes of a society such as that proposed for medical officers of the tuberculosis service are, we may take it, twofold. It primarily, by corporate action, looks after the interests of its members, and secondarily, provides a meeting-place for men engaged in the same work for discussion.

As your previous correspondents have pointed out, there is in existence a tuberculosis society. So far, however, its excellent work seems to have been confined to the consideration of tuberculosis problems more from the purely medical aspect. At present there are 30 tuberculosis medical officers members or fellows of the Society of Medical Officers of Health. It has been suggested that they form themselves, as in the case of the school medical officers, into a group or branch of this society. The formation of such a group would obviate the danger, pointed out by Dr, Thompson Campbell, of the creation of separate societies. The constitution of the Society of Medical Officers of Health provides for the formation of as many district or county branches as may be necessary. The existing organisation likewise provides every facility for a working basis. It is most desirable that all the branches of the public health service should be brought together as much as possible; it would be to the interests of all concerned.

I suggest that the existing Tuberculosis Society take over the tuberculosis medical officer members of the Society of Medical Officers of Health and, if necessary, alter its constitution to meet the altered conditions. It might be named the Society of Tuberculosis Medical Officers and a definite group arrangement be made with the Society of Medical Officers of Health. I trust that negotiations may be opened on such lines.

Meantime, the evident thing for all tuberculosis medical officers to do is to become members of either the Tuberculosis Society or the Society of Medical Officers of Health, pending any such proposed arrangements. The honorary secretary of the former is Dr. W. O. Pitt, 42, Upper Walthamstowroad, Walthamstow, Essex. The offices of the latter are at 1, Upper Montague-street, Russellsquare, W.C.-I am, Sir, yours faithfully,

Lambeth, s.w. S. Nicol Galbraith.

\section{SOUTH AFRICAN CIVIL SURGEONS' DINNER. \\ To the Editor of THE LANCET.}

SIR,-We regret to announce that the South African Civil Surgeons' Dinner will not take place this year, owing to the inadequate response to the cards sent out.--We are, Sir, yours faithfully,

$$
\begin{gathered}
\text { F. E. FREMANTLE, } \\
\text { C. GORDON WATSON, } \\
\text { Harley-street, W., June 23rd, 1914. } \\
\text { Honorary Secretaries. }
\end{gathered}
$$

\section{A PROTEST.}

To the Editor of THE LANCET.

SIR,-The proprietors of "Kutnow's Powder " have used my name in an advertisement of their proprietary article which has recently appeared in the Times. This is without my permission. I have no knowledge of this proprietary article, and have not authorised the use of any of my writings in connexion with this.

I am, Sir, yours faithfully, Loughton, Essex, June 24th, $1914 . \quad$ LEONARD HILL. 